\title{
22
}

\section{RACE, RACISM, AND SOCIAL POLICY}

\author{
Albert Atkin
}

Policy-making must always pay attention to race. That is the central claim of this chapter. To put the claim a little more broadly, I suggest that regardless of whether some particular policy debate is ostensibly "racial", policy-makers must attend to questions of race in their policy discussions. At a first pass, it might seem that a philosophical essay on race, racism, and social policy would do well to focus on a particular set of topics where matters of race seem to be most pertinent to policy - issues such as affirmative action, statistical profiling, or reparations, for instance. Indeed, this is the most common strategy, but the strategy for discussing race and policy that I pursue in this chapter is different and is motivated by three starting points or presuppositions: first, I maintain that philosophical and ethical reflection on social policy ought to be directed towards practical outcomes and real-world impact; second, I maintain that, unlike many current philosophical approaches to race and social policy, we must pay more attention to the social dimensions of race; and third, I argue that race is ubiquitous but frequently unnoticed, and as a result must be a relevant consideration for appropriately cautious policy-makers. I shall expand upon these three starting points in more detail ahead (in Part 1), but crucially they lead back to my central claim that race should always be a matter of consideration for policy-makers, regardless of how remote racial concerns may seem to be from the policy in question. I shall then (in Part 2) explain and support this central claim by introducing an example of the type of philosophical question about race that I think philosophers and policy-makers would do well to examine. In particular, I shall explore how the general racial question "What is race?" is pertinent to policy consideration.

\section{Part 1: starting points}

As I have stated, the central claim I am making in this chapter is that public policy-makers must pay close attention to race, and I shall highlight how they might do this by examining an example question that policy would do to well attend to in Part 2. In this part of the chapter, however, I shall introduce some important starting points that lead me to make this claim about race, philosophy, and policy. In particular, I raise three important issues or questions here: first, how should philosophers be engaging and reflecting on matters of policy-making? Second, how should philosophers be engaging with public policy as it intersects with matters of race? And finally, why think (as I do) that proper philosophical engagement in public policy must have a special onus upon it to attend to the impact of race and racism? We'll look at each point in turn. 
The first starting point for my concerns here, then, is with how philosophers should be engaging with matters of public policy-making. My own philosophical inclinations are broadly pragmatic and pragmatist, and as such, I am sympathetic to the idea that where philosophy and philosophers engage with social policy, they should do so by looking to the practical and pragmatic concerns of real policy-making rather than by becoming preoccupied with applying ethical theory to problems under laboratory conditions, so to speak. More specifically, I am most inclined towards an approach to philosophy and public policy found in Jonathan Wolff (2011), and Jonathan Wolff and Avner de Shalitt (2007), which Wolff characterises as "bottom-up" theorising. In simple terms, bottom-up theorising demands that we approach social policy questions by understanding the real practical problems that give rise to those questions. This is in contrast to a "top-down" approach, where we might start from a prior understanding of ethical theory and ask what a consistent application of that theory requires of our policy-making.

Wolff has various reasons for favouring a bottom-up approach to philosophical engagement with social policy, but I favour his approach because of three particular requirements it asks of us. First, the bottom-up approach requires that we accommodate the fact that the practical requirements of those problems that drive policy debate will change across the history of a policy area. As Wolff $(2011,7)$, borrowing from Joel Feinberg $(1987,18)$, notes, practical concerns mean that we are often engaged with penultimate questions and problems rather than with giving final and ultimate answers. In terms of race and racism, this will mean that our policy objectives are better framed and judged in terms of local and specific issues rather than with final goals in mind. Australians from the Aboriginal and Torres Straight Islander community experience many poor social outcomes primarily due to the racist and racialised settler colonialism of Australia, but the policies which affect these communities must focus primarily on, for instance, implementing clear interim targets for improving access to proper health care rather than focusing on larger-scale, more nebulous objectives, such as 'eradicating racism'. These are, of course, important final aims and ambitions for Australian society, but they are not the kind of objective by which to guide or judge interim policies in the face of appalling disparities in life expectancy, unacceptable child mortality rates, or troublingly high suicide and mental health problems among Aboriginal and Torres Strait Islander groups.

The second thing that a bottom-up approach to policy requires of us is, as already noted, that we focus on practice rather than theory. However, I take this practicalist dimension of bottomup theorising to be especially important in philosophical deliberation on policy and race, and to have a much broader impact than mere appeals to attend to practice first. In particular, I take the practicalist requirement to mean that we must attend closely to real racial experiences, or rather, the experiences of the racialised, in our examination of policy. We can, for example, simply contrast a theory-first approach to affirmative action policy that looks at what our preferred ethical theories suggest about differential treatment with a practice-first approach that looks to current practices of affirmative action and intended outcomes. But I also take it that a practicalist approach means that we should pay especially close attention to the racialised experiences of those for whom race-based affirmative action policies are supposed to apply, and their experiences under the implementation of those policies.

Third, and finally, I take a bottom-up approach to require engagement with the fine detail of practical policy-making, and most importantly, familiarity with the context and history of particular policies. As Wolff puts it,

[S]ome policies may simply be a reflection or hangover of value systems that are outmoded or should never have been accepted in the first place. But history can matter. Existing policies may be cobbled together to respond to previous historical 
circumstances, including policy failure, and being aware of the history of a policy area can help us become sensitive to possible pitfalls with new recommendations.

(Wolff 2011, 7)

In matters of race and public policy, this third element requires that we pay very close attention to the racial history and context of particular policy-making. Now in certain cases - for instance, the bans on interracial marriage famously overturned in the 1967 Loving $v$. Virginia case (Loving v. Virginia, 388 US 1. [1967]) -- the racial origin and context of particular policies are quite clear. In many other policy areas, however, the racial and racialised origin and context are less immediately apparent, and the importance for understanding the racial dimensions of current policy is frequently obscured. In Part 2 of this chapter, I will examine instances where the racial history of certain policies becomes particularly relevant, but for now it's enough to note that by adopting a bottom-up approach to philosophy and policy, we must always seek to understand the racial history of a policy area.

The second starting point for my concerns here is with how philosophers should be engaging with public policy as it intersects with matters of race. Unfortunately, this leads me into some rather negative and curmudgeonly reflection on current philosophical engagements with matters of policy and race. To be brief, proper engagement requires a much fuller understanding of the extensive social nature of race, racism, and the experiences of the racialised than we frequently see in philosophical engagement with race and policy. We shall return to this in discussion at various points in what follows ahead, but the concern is that race is ubiquitous and so intertwined with the nature and origin of the societies in which we live that we must attend to it by acknowledging and incorporating its social and structural nature, rather than by including it in our theorising as a thin and underspecified place-holder for colour-based differential treatment. In this respect, current philosophical reflections on race and public policy are frequently underwhelming. Nonetheless, my hope is that by showing why we might be concerned with current approaches that do not do proper work with race, we can begin to see how proper engagement should proceed.

The complaint here, then, is that where the interaction between race and the philosophy of public policy finds itself confined to particular topics, such as affirmative action, statistical profiling, and reparations, it is frequently under-explored. There is, of course, no reason why a focus on particular topics and racial matters cannot lead to important, insightful, and valuable work on race. Indeed, well-worked-out and full-blooded reflection on race exists in work on, for example, affirmative action (see Anderson 2010), or racial profiling (see Lever 2017). The problem, however, is that when focusing on specific debates with a racial dimension, race usually features as a rather ghostly and anaemic philosophical version of itself. To give some specific but common examples, race usually turns up in policy debates as either a "useful analogy", a "place-holder variable" for any dimension of inequality, or a "filter on some intuition pump" or other. Consider the following illustrative cases.

In various arguments on same-sex marriage or on animal experimentation, for example, race and racism are used as useful analogies. It is obvious, so the arguments go, that we shouldn't and don't insist on same-race marriage, and that the ethical reasoning here is transferable to debate on same-sex marriage (see, e.g., Wedgwood 1999, 240, or Rajczi 2008). Similarly, so the argument goes, the obvious immorality and impermissibility of racism are serviceable as an argument against animal experimentation and "speciesism" - 'speciesism and racism are sufficiently similar so that analogies between them cannot be blithely dismissed as category mistakes' (LaFollette and Shanks 1996, 42). Whatever we might think about the analogical reasoning in these cases, and I think there are serious problems, the problem is that policy debate on marriage equality or 
animal experimentation which uses race in this way pays too little regard to the deep structural dimensions of race, and the wide-ranging social impacts that accrue to racial difference.

Relatedly, race is often used as a place-holder variable for any dimension of differential treatment without paying full attention to what makes racial identity distinct. Discussion of statistical profiling, for example, usually frames itself in terms of criminal racial profiling (Risse and Zeckhauser 2004 or Risse 2007 are good examples), but there isn't often much sense that the positions that emerge from such philosophical reflection here would not have been served just as well by using some other dimension of individual social identity, such as gender, sexuality, or disability. Indeed, as Annabelle Lever notes,

[T] his approach treats racial profiling as one example among many others of a general problem in egalitarian political philosophy, occasioned by the fact that treating people as equals does not always require, or permit, us to treat them the same.

(Lever 2017, 425)

When properly understood, however, race presents a different and complicating set of considerations that do not hold of, say, sexuality or disability, and it is important that we understand just how significant the differences between race, gender, sexuality, and so forth are when it comes to examining race and policy. Indeed, Lever's own work on racial profiling is a good example of how we can take account of the deep structural elements of race - something Lever labels 'the social construction approach' (Lever 2017, 425) - when we engage with race and policy in specific areas of policy debate.

Finally, race is sometimes used as a filter on an intuition pump. An especially good example of this can be found in philosophical discussion of immigration, and especially in Michael Walzer's examination of how far nations are free to self-determine the make-up of their own population (1983, 42-48). For Walzer, racist and racial policies such as the White Australia policy (to which we shall return in Part 2) are simply to be used as test cases for how robust our intuitions about the nation's right to self-determine really are. The ethical and philosophical questions that arise from the racial elements of immigration are actually much deeper and far more socially complex than such a treatment can capture, and proper reflection needs to examine the ethical dimensions of race and racism in immigration policy in a much more thorough way (see Mendoza 2015 and Mendoza 2018).

Obviously, there are other ways in which race features in philosophical work on policy, but these three - as a useful analogy, a place-holder variable, or a filter on some intuition pump are quite common. Now, as previously suggested, the concern here is with how philosophers should engage with race and policy, and the worry expressed in these three example cases is that treating race in these thin, under-explored ways leads to fruitless engagement between policy and race. In particular, such engagement leaves us with philosophical reflection on racial matters that fails to capture the impact and scale of race in a racialised society. Race must be handled in a much more complex and thoughtful way. Indeed, even in the discussion of these examples I mentioned work by Elizabeth Anderson, Annabelle Lever, and Jose Jorge Mendoza, which is among a growing body of philosophical engagement with questions of social policy that does engage with race in a deeper and more fruitful way.

The third and final starting point for my concerns here is with why we should think there is a special onus in philosophy and policy to engage with race. And in fact, the point here is the rather simple claim that race is a complex and ubiquitous social presence, but for large parts of society, almost completely unnoticed. It is helpful, I think, to divide this concern into two points: first, that contemporary society is founded upon and functions through a set of racial 
and racist structures and institutions; and second, that our society is geared to the normativity of whiteness.

To expand slightly, the reason these two points lead to the claim that race is ubiquitous but unnoticed is that, on the one hand, contemporary democratic societies are founded on a series of philosophical views which divide the world into racialised hierarchies. Charles Mills famously describes this in his book The Racial Contract (Mills 1997), and in later work notes the racism inherent the views of philosophers such as Hobbes, Locke, Rousseau, and Kant:

Hobbes depictions of Native Americans as "savages" still in the (apparently real for them) state of nature; Locke's investments in the slave-trading Royal Africa Company, his role in writing the Carolina Constitution, and his representation of Native Americans and incompetent appropriators; Rousseau's limiting of contemporaneous savagery and his non-condemnation of African slavery; and (the easiest case) Kant's racial hierarchy.

(Mills 2017, 69)

The racialised views of these figures (and others besides, including Hume, Hegel, John Stuart Mill, and Adam Smith) provide many of the philosophical foundations and justifications for organising contemporary society. Unsurprisingly, these racialised views find themselves everywhere embedded within the tools and institutions of our societies.

In terms of the normativity of whiteness, on the other hand, whiteness is both privileged by the ease with which it can navigate the racialised social structures made by and for white people (see Sullivan 2006), and made normative in virtue of treating race as something other groups in the hierarchy have as a result of failing to be white. This has the interesting effect of making white people largely unaware of the impact and presence of race at large, and seldom aware of their own race, As the black academic Patricia Williams notes,

You need two chairs at the table: one for you and one for your blackness. For white people, moreover, racial denial tends to engender a profoundly invested disingenuousness, an innocence that amounts to the transgressive refusal to know. Again this is not to assign anything like blame, simply to observe the way in which we know race or don't.

(Williams 1997, 27)

Between the overriding presence of racialised structures in society, and the normativity of whiteness, we can see the substance of the claim that race is ubiquitous, but largely unnoticed by large parts of society. In short, racial hierarchies are used to build and maintain society to the advantage of white people, but white people are invested in not seeing their own race, or its role in securing their position at the top of these hierarchies. Or to borrow a well-worn idiom, fish are the last to discover water.

The simultaneous ubiquity and invisibility (to the beneficiaries of racial privilege) of race are relevant to my concerns here, though, because, as mentioned, I take it to introduce a particular onus upon those considering philosophy and policy to attend to race. More specifically, philosophy as an academic discipline is remarkably white. Similarly, those in the position to develop and influence policy-making are remarkably white. It would be unsurprising, then, if somewhere between the whiteness of philosophy and the whiteness of policy-making, the ever-present impact and influence of race go unnoticed. For philosophers interested in policy, this means that the risk of passing race by without noticing its influence gives us reason to think 
Albert Atkin

some special provision must be made to ensure that race is not passed by, but instead properly attended to in policy deliberations.

These three starting points for considering race and public policy may seem fairly involved, but it should hopefully be clear why I take them to matter. Bottom-up theorising means getting to grips with the fine detail of policy at the real interface between policy-making and the racialised experiences of those it impacts upon. The proper way for philosophers to engage with race in matters of policy is not by treating race as a thin, abstracted theoretical tool but by attending to the complex social conditions that have given life to it, and which maintain it. And finally, because of the ubiquity of race and the whiteness of philosophy and policy-making, responsible reflection must ensure that race is not being missed, unnoticed, or merely given lip-service. This, I take it, is enough to at least give some sense of my claim that policy must always pay attention to race.

\section{Part 2: race and policy}

In the preceding section, I gave three starting points for my claim that philosophical engagement with social policy must always address race. In this part of the chapter I will try to give an extended example of the type of question about race that might very well play a role in guiding those engaging with race and policy. My particular concern will be with the importance of addressing the question 'what is race?'. There are other questions which we might easily identify as being important here - 'who defines racial membership?', or 'what are we using race for?', for instance. Obviously, these are all fairly general racial questions for philosophers reflecting on policy to engage with, and I certainly do not mean to suggest that asking general (non-policy-specific) questions about race is the only way to address the issue of race in policy. Indeed, throughout the preceding section I mentioned work by philosophers who are engaging with quite specific policy questions about race in what seems to me to be exactly the right spirit. Rather, what I am suggesting here is that regardless of whether we are not dealing directly with racial policy debates, such as race-based affirmative action or criminal racial profiling, there are important general racial questions that we must be aware of. The example used ahead - 'what is race?' - is, I think, the clearest example of why policy-makers must ask higher-level, more general questions about race.

\section{What is race?}

It is important that philosophers engaging with policy attend to the issue of what race is, and what type of conception of race they might be working with in policy deliberation. In many ways, this draws most directly upon the second starting point discussed in Part 1, where I suggested that race is a deep and complex socially constructed phenomenon, and that proper engagement with it in policy questions must attend to this dimension. Indeed, my complaint against much contemporary philosophical engagement with race and policy is that it frequently fails to do this. Here, though, I want to explore the relevance of raising this question by first contrasting two dimensions of our current understanding of race - the biological dimension, and the social dimension before secondly, looking at some reasons why this difference matters to policy debate.

\section{Biological race v. social race}

Race is a curious and troublesome concept, and for all the reasons one might expect: it's hard to say precisely what it is or what makes someone one race rather than another; it is the foundation for some of the most unsavoury aspects of human behaviour and history, and so on. But it 
is made especially curious and troublesome because it has two elements, one biological and the other social. To be more precise, race is really a set of biological pretensions which ground a set of very real social constructions and constraints. This becomes troublesome in many discussions of race, however, because the biological pretensions and the social constraints frequently come apart, and the biological dimension tends to dominate our reflections upon race.

Race, viewed in biological terms, is best understood through the question of whether race as we understand it and use it has any substantial corollary in the biological sciences. As it happens, it doesn't, or at least this is what informed consensus suggests, but this doesn't stop a certain level of philosophical engagement and discussion of race in biological terms, not least because race as a concept has pretensions to be a robust scientific fact.

The idea that race and racial difference are a matter of biological fact is due in part to the origin of the modern concept in the enlightenment science of Linneaus (1758), Blumenbach (1795), and Kant (1775), among others. What we find among these thinkers is an essentialising view of race whereby the external bodily markers of race - skin colour, hair type, nose shape, and so on - come to be explained in terms of some deep underlying biological difference connected to breeding and ancestry. This construal of race in essentialist terms more or less gives us our modern concept, and even though we know that enlightenment scientific essentialism about race is empty, we still see contemporary questions about the underlying biology of race engaging racial difference in terms of genetic difference. Are races sub-species or, in much of the most recent debates about the biological reality of race, population clusters? General consensus is that whatever the biological sciences might suggest about human groups and populations, there is nothing to support the idea that race as ordinarily understood is a robust biological category (see, e.g., Lewontin 1972, Zack 2002, Hochman 2013, or Atkin 2017). Importantly, though, debate about whether race tracks some real biological category or is largely specious tends to be a core component of much philosophical reflection on race.

The other dimension to our contemporary view of race is that, partly because of the enlightenment's construal of race as a biologically robust category, it has been used to construct and justify a set of social conditions and constraints according to the racial categories it creates. This has led to different treatment and expectations for different races within society as a result. Looking at race in social terms, we see that being an Aboriginal and Torres Strait Islander in Australia, for example, is a matter of being subject to a set of specific social conditions and expectations in virtue of the perceived physiological and biological markers used to delineate Aboriginal and Torres Strait Islanders from other races in Australia. This is in contrast to the set of social conditions and expectations that white Australians are subject to in virtue of the perceived markers of whiteness. This manifests itself in terms of different social outcomes whereby white Australians have much better experiences in education and so much higher rates of educational attainment; white Australians have much better access to health care in the Australian health care system and so have remarkably higher life expectancy rates; and so on.

The sociocultural and historical practices surrounding the use of race and racial difference are, in many ways, the more important and interesting element of examining what race is. The biological pretensions of race are really nothing more than a flimsy justification for the deep differential treatment that manifests itself in the social reality of race. For this reason, then, it is important that we attend to the differences between race and racial categories as they arise from its social, rather than biological, dimension. To give an example of how this difference affects our understanding, consider the case of swimming in the United States:

Black Americans are less likely to be able to swim than their white counterparts. Early (and specious) biological explanations of racial difference put this disparity down to underlying 
Albert Atkin

physiological differences between the races. According to this claim, higher bone density, lower lung capacity, or even higher basal metabolic rate make black people less buoyant and so less capable at swimming (Allen and Nickel 1969). By taking account of the social dimensions of race in the United States, however, we see that black Americans are currently and historically more likely to live in areas where there is no proper access to swimming pools or functional swimming programs, and that even where there is access to usable pools and programs, black people have historically faced exclusion and discrimination in those venues. One upshot is that swimming is simply not part of black American culture (Wiltse 2014); another is that black Americans die from accidental drowning in proportionally higher numbers (Hastings et al. 2006). It should, I hope, be obvious, why policy-makers interested in doing something about higher rates of accidental drowning amongst black Americans would do well to avail themselves of the difference between the biological and social dimensions of race here.

\section{Why does it matter to policy?}

Turning to why policy-makers (and philosophers reflecting on policy-making) need to pay close attention to the difference between the biological and social dimensions of race, the example of black swimming in the US ought, I think, to be instructive. It is clear, in such a case, that a focus on the biological dimension would likely lead to one type of policy response, while a focus on the social dimension would likely lead to another. Moreover, it ought to be clear that the social dimension is probably the most pressing in this case. However, as much of the complaint in Part 1 suggests, there is a tendency among philosophers to focus on the thinner biological dimensions of race. The concern here, though, is with the claim that philosophers and policy-makers would do well to attend to the question "What is race?" and to ensure that they are paying sufficient attention to the social dimension of race and racialisation. I want, then, to conclude this section by looking at two reasons for thinking that attending to this question (what is race?) in this way (by focusing on its social dimensions) matters to policy.

The first reason we should pay close attention to whether we are focusing on the biological or social dimensions of race is that too heavy a focus on biological questions and the biological pretensions of race has a corrupting effect on policy-making. An especially good example of how a focus on the biological dimensions of race corrupts policy-making is given in a recent paper by Tina Fernandes Botts (Botts 2017). Botts notes that there is a discernible shift in the Supreme Court of the United States' understanding of race from a social to a biological phenomenon. This she argues leads to a change in the court's understanding of when the Equal Protection clause applies, and a change in their general understanding of what counts as racial discrimination and to whom it applies. As Botts points out,

[A]s the US Supreme Court's concept of race moves from being understood as a sociocultural/sociohistorical phenomenon to being understood as a purely biological phenomenon, there is a concomitant shift on the part of the Court from understanding racial discrimination as problematic because it reinforces the legacy and vestiges of American chattel slavery, to understanding racial discrimination as problematic per se.

(Botts 2017, 526)

The effect of adopting this view of race as a putative biological category, she argues, is that Supreme Court decisions treat any attention to race or differential treatment of race as 
unconstitutional; why should black people or white people be excluded from some position or opportunity in society because of a biological fact over which they have no control? The knock-on effect on policy, however, is dramatic. Affirmative action programs in the United States, for example, are increasingly abandoned on the grounds of upheld cases of racial discrimination against excluded white applicants (e.g., Gratz v. Bollinger, 539 US 244 [2003]). Unfortunately, such reasoning by-passes the social dimension of race, where we can see quite clearly that racial discrimination is not simply any differential treatment on the basis of race, but should be properly understood as the product of America's long-standing cultural and historical disposition to treat black people as (considerably) less than the equal of white people.

What Botts shows us in her discussion of equal protection law in the United States is just how problematic a narrow focus on the biological dimension of race can be for policy debate. On a biological view of race, racial discrimination in the US is any form of differential treatment attributable to racial difference. On a social view of race, however, racial discrimination is differential treatment which compounds and reinvents the subjugation and oppression of black (and other non-white) Americans as part of the ongoing legacy of chattel slavery. Indeed, at a broader level, the corrupting effect of this focus on race as biological is shown in the overwhelming American political tendency towards race-neutral policy-making (Lieberman 2005), and tip-toeing around white discomfort with dissent towards white racial privilege.

The second reason why we should attend to the question "What is race?" and ensure we are accounting for its social dimensions is that viewing race in biological terms often masks the role that apparently non-racial policy has played in the social construction of race. If we are to engage in bottom-up theorising about policy, to engage with race in its fullest and most socially robust sense, and to acknowledge the simultaneous ubiquity and hiddenness of race, we must be careful not to let a biological conception of race keep us ignorant of the sometimes hidden racial dimensions of policy areas. By way of illustration, consider the example of immigration policy.

If we treat race as a merely biological matter, and we view immigration policy as a matter of nations exercising their rights to control borders and population, it's not so straightforward to see how immigration policy is deeply racial. It's true, of course, that much populist sentiment about immigration is driven by barely concealed racism, but policy-making seldom makes explicit appeal to racial difference in demarcating acceptable immigration. Nonetheless, there is almost always the feeling that the practical application of immigration policy has the undertone of racial vetting, which is unsurprising given the role that immigration policies have played in the social construction of national identities, racial hierarchies, and the prescription of acceptable racial categories. At this point, though, we are looking at race in social (rather than biological) terms, and at the role immigration policy has played in the making and maintaining of race as a social category.

To elaborate, both the United States and Australia have, in the past, enforced anti-Chinese immigration policies - the US's Chinese Exclusion Act (1882) and Australia's Immigration Restriction Act (1901). In such instances, policy-makers were clearly intent upon determining the racial make-up of their countries, and imposing whiteness as a normative standard of acceptability. The political instigator of the Australian Immigration Restriction Act (1901), Prime Minister Edmund Barton, argued explicitly in Parliament that 'the doctrine of the equality of man was never intended to apply to the equality of the Englishman and the Chinaman', and in reflecting on the "success" of the policy in 1903, Australia's second prime minister, Alfred Deakin, stated that

The alien coloured population is being steadily reduced. [. . .] A white Australia does not, by any means mean only the preservation of the complexion of the people of this 
Albert Atkin

country. It means the multiplying of their homes, so that we may be able to occupy, use and defend every part of our continent; it means the maintenance of conditions of life fit for white men and white women; it means equal laws and opportunities for all.

(Quoted in Cook 1999, 179)

Viewing race socially, then, makes the racial nature of immigration policy clear. It is, and has long been, a tool for the construction and maintaining of racial hierarchies, and for the privileging of whiteness. Such reflection should, in turn, change the nature and impetus behind our philosophical engagement with immigration policy-making. We can no longer raise questions about immigration policy and freedom of association or governmental right to self-determination as though such matters are simply race-neutral. We should, instead, try to acknowledge and accommodate the racial nature of ethical questions about immigration in our public policy deliberation.

To give one illustration of how this might matter, once the social dimension of race in immigration is made clearer we can see how the "racial vetting" aspect of such policies has important social impacts upon existing racial groups within nations. Recent work on "linked fate" in the American Latinx ${ }^{1}$ community, for instance, shows that the prominent "anti-Hispanic" sentiment of US immigration policy since 2001 creates a greater sense of linked fate among Latinx Americans (Vargas et al. 2017). We can think of "linked fate" as individual recognition of shared membership in, and so shared status, outcomes, and interests with, marginalised groups (Dawson 1994). As prominent immigration policies focus on the exclusion and removal of Latinx immigrants, Latinx Americans see their own social status as linked to those who are excluded. This has a direct impact upon the social status and position of Latinx Americans who feel that arguments for the exclusion of the Latinx immigrants they identify with simultaneously denigrate them as an economic burden and place them at odds with America's concept of itself. Such racial elements of immigration policy as these become clear, however, only once we start to analyse race more fully along its social, rather than biological, dimension.

The history of immigration policy in places such as Australia, then, makes for a relatively clear example of how treating race as biological rather than social can mask the role that policy has played in constructing racial hierarchies, and continues to play in maintaining those structures. It is not the only case we might have discussed here, and I would argue that when examined closely, much policy-making has been implicit in creating dominant racial structures, and by extension in maintaining structural racism.

We might have mentioned marriage policies, for example, by which the state has destabilised and devalued minority family structures and imposed white family structures as normative (Pinderhughes 2002). When viewed this way, it is unsurprising that state intervention into black families in the US or Aboriginal families in Australia is disproportionately high, given that such family structures here are deemed unorthodox or are pathologised in virtue of not being white. Relatedly, we might have mentioned adoption policy debates which frequently bypass the role that adoption has played, and still plays, in state control of racial groups, the assimilation of minorities, and in some cases the intended eradication of races. The primary tools by which Australia, during its own racial formation, controlled its Aboriginal population was through forced adoption programs and what has come to be known as 'the stolen generation' (Read 1983). Similarly, in post-Ceausescu Romania of the 1990s, Roma children were taken from their families and placed into international adoption programs, which, alongside the forced sterilisation of Roma women, was used as a means of controlling the Gypsy Roma population (Kligman 1998). It is unsurprising, then, that while children from racial minority groups are often overrepresented in foster and adoptive care systems, families from racial minorities are reluctant to take on the role of adoptive parents and are usually underrepresented in the system. 
This puts much debate on adoption policy (and not just the ethics or politics of interracial adoption) in a different light.

We could continue by looking at, for instance, the racialised nature of education (Woodson 1933/1998) and the impact of education policy on people from minority groups (Derrington 2007). However, the general point here is that policy-making is itself part of the tool kit by which race is made, and through which oppressive racial hierarchies are maintained. It is part and parcel of what makes the practical racial experiences of the members of any given society. It is implicit in masking the influence of race for those at the top of any given racial hierarchy. Policy is one of the primary tools by which race is made ubiquitous, and it is one the chief mechanisms by which race is hidden from and for white people. This means that without proper attention to the social dimension of race and its connection to social policy, our philosophical reflection on policy-making is at best severely hampered, and at worst remains complicit in maintaining racial privilege.

\section{Conclusion}

What I have tried to do in this chapter is, by showing my own starting points, motivate the claim that good policy-making (and philosophical engagement with it) must always pay attention to race. The argument is, I think, straightforward. The call to attend to practical concerns and social impacts in policy, the call to attend to the thick social construction of race, and the call to acknowledge that race is a prominent but unnoticed thread in our social fabric all seem to me to make the claim that race should always be a consideration for policy quite natural. The social dimension of race means policy is often an instrumental part of how race is made and maintained; the call to bottom-up theorising means we must look to the history and role that race plays when examining a policy's practical impact; and the simultaneous ubiquity and hiddenness of race means we must be especially vigilant in looking for the traces of race and racism in our social policy regardless of whether they seem to be there upon first inspection. I also take such a call to mean that the way that the philosophical examination of race and racial policy might proceed is different to more orthodox approaches. In particular, I think that much reflection on policy would do well to pause and ask the type of question about race and policy that I posed here with the question "What is race?". Engagement with race at the level of specific policy questions still seems to me to be viable, important, and pursuable in the right way, but engagement with race at this more general level for all policy reflection is crucial.

\section{Note}

1 "Latinx" is used here as a gender-neutral alternative to the term "Latino".

\section{References}

Allen, R.L. and Nickel, David. (1969). "The Negro and Learning to Swim: The Buoyancy Problem Related to Reported Biological Differences". The Journal of Negro Education 38(4): 404-411.

Anderson, Elizabeth. (2010). The Imperative of Integration. Princeton, NJ: Princeton University Press.

Atkin, Albert. (2017). "Race, Definition, and Science". In The Oxford Handbook of Philosophy and Race. Edited by Naomi Zack. 139-150. Oxford: Oxford University Press.

Barton, Edmund. (1901). "Immigration Restriction Bill". House of Representatives, Debates, 26 September, p. 5233.

Blumenbach, Johann Friederich. (1795). "On the Natural Variety of Mankind”. In Race and the Enlightenment. Edited by Emmanuel Chukwudi Eze. Cambridge: Blackwell.

Cook, Ian. (1999). Liberalism in Australia. Oxford: Oxford University Press. 
Albert Atkin

Dawson, Michael C. (1994). Behind the Mule: Race and Class in African American Politics. Princeton, NJ: Princeton University Press.

Derrington, C. (2007). "Fight, Flight and Playing White: An Examination of Coping Strategies Adopted by Gypsy Traveller Adolescents in English Secondary Schools". International Journal of Education Research 46(6): 357-367.

Feinberg, Joel. (1987). Harm to Others. New York: Oxford University Press.

Fernandes Botts, Tina. (2017). "The Concept of Race and Equal Protection Law". In The Oxford Handbook of Philosophy and Race. Edited by Naomi Zack. 526-536. Oxford: Oxford University Press.

Hastings, Donald, Sammy Zahran, and Sherry Cable. (2006). "Drowning in Inequalities: Swimming and Social Justice". Journal of Black Studies 36(6): 894-917.

Hochman, Adam. (2013). “Against the New Race Naturalism”. The Journal of Philosophy 110(7): 331-351.

Kant, Immanuel. (1775). "Of the Different Races of Human Beings". In Anthropology, History and Education. Edited by Robert Louden, translated by G. Zoller and R. Louden. 82-97. Cambridge: Cambridge University Press.

Kligman, Gail. (1998). The Politics of Duplicity: Controlling Reproduction in Ceausescu's Romania. Berkeley, CA: University of California Press.

LaFollette, Hugh and Shanks, Niall. (1996). "The Origin of Speciesism”. Philosophy 71(275): 41-61.

Lever, Annabelle. (2017). "Racial Profiling and the Political Philosophy of Race". In The Oxford Handbook of Philosophy and Race. Edited by Naomi Zack. 425-435. Oxford: Oxford University Press.

Lewontin, Richard D. (1972). “The Apportionment of Human Diversity”. Evolutionary Biology 6: 381-398.

Lieberman, Robert. (2005). Shaping Race Policy: The United States in Comparative Perspective. Princeton, NJ: Princeton University Press.

Linneaus, Carolus. (1758). "Systema Naturae". In Race and the Enlightenment, Edited by Emmanuel Chukwudi Eze. Cambridge: Blackwell.

Mendoza, Jose Jorge. (2015). The Moral and Political Philosophy of Immigration: Liberty, Security and Equality. New York: Lexington.

Mendoza, Jose Jorge. (2018). "Philosophy of Race and the Ethics of Immigration". In The Routledge Companion to the Philosophy of Race. Edited by Paul Taylor, Linda Alcoff, and Luvell Anderson. New York: Routledge.

Mills, Charles. (1997). The Racial Contract. Ithaca, NY: Cornell University Press.

Mills, Charles. (2017). "Philosophy and the Racial Contract". In The Oxford Handbook of Philosophy and Race. Edited by Naomi Zack. 65-76. Oxford: Oxford University Press.

Pinderhughes, E. (2002). "African American Marriage in the 20th Century". Family Process 41(2): 269-282.

Rajczi, Alex. (2008). "A Populist Argument for Legalising Same-Sex Marriage”. The Monist 94(3-4): 475-505.

Read, Peter. (1983). The Stolen Generations: The Removal of Aboriginal Children in New South Wales 1883 to 1969. NSW Ministry of Aboriginal Affairs, Occasional Paper No. 1. 1983.

Risse, Mathias. (2007). "Racial Profiling: A Reply to Two Critics". Criminal Justice Ethics 26(1): 4-19.

Risse, Mathias and Zeckhauser, Richard. (2004). "Racial Profiling". Philosophy \& Public Affairs 32(2): 131-170.

Sullivan, Shannon. (2006). Revealing Whiteness: The Unconscious Habits of Racial Privilege. Bloomington, IN: Indiana University Press.

Vargas, Edward D. Sanchez, Gabriel, R. and Valdez Jr., Juan A. (2017). "Immigration Policies and Group Identity: How Immigrant Laws Affect Linked Fate among U.S. Latino Populations”. Journal of Race, Ethnicity and Politics 2(1): 35-62.

Walzer, Michael. (1983). Spheres of Justice: A Defense of Pluralism and Equality. New York: Basic Books.

Wedgwood, Ralph. (1999). "The Fundamental Argument for Same-Sex Marriage”. The Journal of Political Philosophy 7(3): 225-242.

Williams, Patricia. (1997). Seeing a Color-blind Future: The Paradox of Race. New York: The Noonday Press.

Wiltse, Jeff. (2014). "The Black White Swimming Disparity in America: A deadly Legacy of Swimming Pool Discrimination”. Journal of Sport and Social Issues 38(4): 366-389.

Wolff, Jonathan. (2011). Ethics and Public Policy: A Philosophical Inquiry. London: Routledge.

Wolff, Jonathan and De-Shalitt, Avner. (2007). Disadvantage. Oxford: Oxford University Press.

Woodson, Carter G. (1933/1998). The Miseducation of the Negro. Trenton, NJ: Africa World Press.

Zack, Naomi. (2002). Philosophy of Science and Race. New York: Routledge. 